\title{
Usporedbe vrijednosti intraokularnog tlaka mjerene air-puff (nekontaktnom) tonometrijom i Goldmanovom aplanacijskom tonometrijom
}

\section{Comparisons of intraocular pressure values measured by air-puff (non-contact) tonometry and Goldmann applanation tonometry}

\author{
Marija Olujić ${ }^{1 *}$, Ivana Šimić ${ }^{2}$, Darko Kotromanovićc ${ }^{3}$ Dubravka Biuk ${ }^{4}$, Maja Miškulin ${ }^{5}$, \\ Romana Marušićs, Vesna Bilić-Kirin², Ivan Miškulin ${ }^{5}$
}

\begin{abstract}
Sažetak. Cilj: Ciljevi istraživanja bili su utvrditi postoji li razlika u mjerenju intraokularnog tlaka (IOT) Goldmanovom aplanacijskom tonometrijom (GAT) i air-puff tonometrijom (APT) te usporediti osjećaj ugode prilikom mjerenja IOT-a objema metodama. Ispitanici i metode: Ovom presječnom studijom obuhvaćena su 133 ispitanika kojima je učinjen standardni oftalmološki pregled. Ispitanici su na pregled dolazili zbog korekcije refrakcijske greške od listopada 2017. do travnja 2018. godine na Polikliniku za oftalmologiju „Oculus” u Osijeku. Isključni kriteriji bili su dob manja od 18 godina, liječenje od glaukoma, operativni zahvat na prednjem ili stražnjem segmentu oka, degenerativne promjene na prednjem segmentu oka ili teži poremećaj suznog filma. Svim ispitanicima izmjeren je IOT objema metodama, nakon čega su ispitanici dobrovoljno ispunili anketu u kojoj su se prikupljali sljedeći podatci: dob, spol, nošenje leća, broj pregleda mjerenja IOT-a te procjena ugodnosti pregleda GAT-om i APT-om. Rezultati: Presječna studija uključila je 133 pacijenta ( 83 žene, 50 muškaraca). Medijan dobi ispitanika bio je 51 godina. Utvrđena je statistički značajna razlika između izmjerenog IOT-a desnog i lijevog oka GAT-om i APT-om (t-test za zavisne uzorke, $P<0,001$ ). Nije bilo statistički značajnih razlika u ocjeni ugode mjerenja IOT-a GAT-om i APT-om (Fisherov egzaktni test, $P=0,180$ ). Zaključci: lako APT ima određene prednosti u odnosu na GAT, GAT daje preciznije rezultate mjerenja IOT-a te se $s$ razlogom danas smatra zlatnim standardom u mjerenju IOT-a.
\end{abstract}

Ključne riječi: intraokularni tlak; oftalmologija; tonometrija
${ }^{1}$ Dom zdravlja Osječko-baranjske županije, Osijek, Hrvatska

${ }^{2}$ Zavod za javno zdravstvo Osječko-baranjske županije, Osijek, Hrvatska

${ }^{3}$ Zavod za onkologiju, KBC Osijek, Osijek, Hrvatska

${ }^{4}$ Klinika za očne bolesti, KBC Osijek, Osijek, Hrvatska

${ }^{5}$ Sveučilište J. J. Strossmayera u Osijeku, Medicinski fakultet Osijek, Osijek, Hrvatska

\begin{abstract}
Aim: The objectives of the study were to determine whether there is any difference in the measurement of intraocular pressure (IOP) by Goldmann applanation tonometry (GAT) and air-puff tonometry (APT) and to compare the feeling of comfort when measuring the IOP by both methods. Participants and methods: This cross-sectional study included 133 participants, who underwent standard ophthalmic examination. Participants were examined for correction of refractive error from October 2017 to April 2018 at the Ophthalmology polyclinic "Oculus", Osijek. Exclusion criteria were age under 18 years, glaucoma treatment, operative surgery at the anterior or posterior eye segment, degenerative changes in the anterior eye segment, or tear film disorder. IOP was measured in all participants by both methods, after which participants voluntarily completed a questionnaire in which the following data were collected: age, gender, data on wearing lenses, number of IOP measures, and evaluation of the comfort level of GAT and APT. Results: This cross-sectional study included 133 patients ( 83 women, 50 men). The median of the participants' age was 51 . There was a statistically significant difference between the measured IOP of the right and left eye with the GAT and APT (t-test, $P<0.001$ ). There was no significant difference in the comfort level of IOP measured with GAT and APT (Fisher's exact test, $P=0.180$ ). Conclusions: Although APT has some advantages over GAT, GAT provides more accurate results for IOP measurement and is therefore considered a gold standard for IOT measurement today.
\end{abstract}

Key words: intraocular pressure; ophthalmology; tonometry

\author{
*Dopisni autor: \\ Marija Olujić, dr. med. \\ Dom zdravlja Osječko-baranjske županije, \\ Osijek, Hrvatska, Biševska 32, 31000 Osijek, \\ Hrvatska \\ E-mail: molujic9@gmail.com
}

http://hrcak.srce.hr/medicina 


\section{UVOD}

Očni ili intraokularni tlak (IOT) pritisak je sadržaja očne jabučice na njezine stijenke ${ }^{1}$. Srednja vrijednost IOT-a u zdravih osoba procjenjuje se na 15 do $16 \mathrm{mmHg}$ sa standardnom devijacijom od oko $3,0 \mathrm{mmHg}$. Normalna vrijednost IOT-a definira se kao dvije standardne devijacije iznad normale, tj. $21 \mathrm{mmHg}$ te se vrijednosti iznad toga smatraju povišenima. Vrijednost IOT-a najvažniji je rizični čimbenik za razvoj i progresiju glaukoma². Posto-

Goldmanova aplanacijska tonometrija smatra se zlatnim standardom u mjerenju intraokularnog tlaka jer daje preciznije rezultate mjerenja intraokularnog tlaka, u odnosu na air-puff tonometriju.

janje očne hipertenzije bez glaukomskih promjena na vidnom živcu i u vidnom polju, kao i postojanje glaukoma s normalnim vrijednostima IOT-a, govori da povišeni IOT ne znači nužno i glaukomsku bolest ${ }^{3}$. Dnevne varijacije IOT-a mogu biti znatne, a izraženije su u bolesnika s glaukomom nego u zdravih pojedinaca ${ }^{2}$.

Mjerenje IOT-a je mjerenje pritiska sadržaja očne jabučice na njezine stijenke ${ }^{3}$. Tonometrija se temelji na međuodnosu IOT-a i odgovarajuće sile koja je potrebna da se normalni oblik rožnice deformira (izuzev dinamičke konturne tonometrije). Biomehanička svojstva rožnice, kao što su debljina i elastičnost, mogu utjecati na izmjerenu vrijednost IOT-a². Tonometrija se može odrediti digitalno i pomoću instrumenata ${ }^{4}$.

Digitalna je metoda orijentacijska, subjektivna metoda određivanja tvrdoće očne jabučice, a koristi se u kliničkoj praksi kada instrumentalno mjerenje nije moguće. Kažiprstima obje ruke preko gornje vjeđe palpira se očna jabučica. Vrijednosti tonusa iskazuju se od -3 do -1 za hipotenziju, $\mathrm{N}$ za normotenziju te od +1 do +3 za hipertenziju očne jabučice. Posebice je važno ocijeniti postojanje interokularne razlike 2 .

Aplanacijska tonometrija instrumentalna je metoda mjerenja očnog tlaka koja se temelji na zaravnjavanju rožnice. Najčešće korišteni tonometar i zlatni standard jest Goldmanov aplanacijski tonometar (GAT), instaliran na biomikroskopu.
Tijekom kontakta prizme tonometra sa suznim filmom i rožnicom postoji opasnost od prijenosa infekcije. Kemijska dezinfekcija i upotreba jednokratnih tonometara smanjuje rizik mogućeg prijenosa infekcije. Pogrješke tijekom mjerenja GAT-om mogu biti posljedica neodgovarajuće tehnike mjerenja, kao i bioloških varijabilnosti oka i orbite ${ }^{2}$. Izmjerena vrijednost ovisi o svojstvima rožnice, prije svega o debljini, hidriranosti i zakrivljenosti te o količini suza na rožnici ${ }^{3}$. Najvažniji utjecaj pritom ima centralna debljina rožni$\mathrm{ce}^{2}$. Izmjerenu vrijednost IOT-a potrebno je korigirati prema konverzijskim tablicama za vrijednosti pahimetrije kako bi se dobila stvarna vrijednost IOT-a. Ako je rožnica deblja, pruža veći otpor pritisku tonometra pa je stvarni IOT niži, a ako je tanja, otpor pritisku tonometra je manji te je tlak viši od izmjerenog ${ }^{3}$.

Nekontaktni tonometar ili air-puff tonometar (APT) temelji se na Mackay-Marganovom načelu i mjeri IOT neinvazivno aplanacijskom tonomterijom. Prilikom mjerenja koristi brzi zračni val kojim se površina rožnice izravna. Prednosti uključuju brzinu, nije potrebno korištenje lokalne anestezije i nema izravnog kontakta s rožnicom ${ }^{2}$. APT se mora koristiti na određenoj udaljenosti od rožnice, stoga instrument uključuje optički sustav kako bi se to olakšalo. Sam zračni val može svojom prividnom silom i bukom koju proizvodi zastrašiti pacijenta $^{5}$, stoga je nekim pacijentima APT neugodan $^{2}$. APT može biti prijenosni i neprijenosni, a budući da je riječ o nekontaktnom tonometru, rizik od prijenosa infekcije s jednog oka na drugo putem uređaja eliminiran je. Međutim, snaga zračnog vala može aerosolizirati suzni film i teoretski se mogu prenijeti virusi zračnom strujom ${ }^{5}$. Od preostalih tonometara u uporabi su: dinamički konturni ili Paskalov tonometar (engl. Dynamic Contour Tonometer - Pascal), analizatori očnog odgovora (engl. Ocular Response Analyser; ORA), Ocuton S, Tono-Pen, transpalpebralni tonometar (engl. Transpalpebral Tonometer) i Triggerfish ${ }^{\circledR}$ (Sensimed $)^{2}$.

Centralna debljina rožnice utječe na vrijednosti IOT-a izmjerene GAT-om, međutim, za sada nije definiran točan i koristan algoritam odnosa GAT-a i centralne debljine rožnice. Normalna raspodjela vrijednosti centralne debljine rožnice iznosi $540 \pm$ 
$30 \mu \mathrm{m}$ (srednja vrijednost \pm standardna devijacija) $)^{2}$. Na periferiji debljina rožnice iznosi oko $700-$ $900 \mu^{3}$. Promjene centralne debljine rožnice nakon refraktivnih operacija na rožnici otežavaju interpretaciju GAT-a. Predoperacijsko mjerenje centralne debljine rožnice pahimetrijom korisno je za pacijente kojima se planira refraktivna kirurgija rožnice ${ }^{2,6}$. Sama pahimetrija postupak je mjerenja debljine rožnice ultrazvukom (kontaktno) ili optičkom (nekontaktnom) metodom ${ }^{3}$. Pahimetrija se osim u refraktivnoj kirurgiji koristi i kod praćenja bolesti rožnice te je čimbenik korekcije vrijednosti izmjerenog IOT-a aplanacijskom tonometrijom².

Ciljni IOT gornja je granica vrijednosti IOT-a za koju se očekuje da će biti kompatibilna s dovoljno sporom progresijom da se održi kvaliteta života povezana s vidom u očekivanom životnom vijeku bolesnika. Ciljni tlak treba redovito reevaluirati, pogotovo ako se utvrdi progresija bolesti ili ako se pojave druge komorbiditetne očne ili sistemske bolesti. Nema jedinstvene ciljne vrijednosti IOT-a koja bi vrijedila za sve bolesnike pa je važno za svakog oboljelog individualno procijeniti njegov ciljni IOT. Čimbenici koje treba uzeti u obzir prilikom određivanja ciljnog IOT-a jesu: stadij bolesti (za veće postojeće oštećenje potreban je niži ciljni IOT), vrijednosti IOT-a prije terapije (što su vrijednosti IOT-a prije terapije niže, potrebna je niža vrijednost ciljnog IOT-a), dob i očekivani životni vijek (u mlađih ljudi dulje je očekivano vrijeme života pa je potreban niži ciljni IOT), stopa progresije tijekom razdoblja praćenja (što je brža stopa progresije, potreban je niži ciljni IOT), pojava drugih rizičnih čimbenika (npr. pseudoeksfolijativni sindrom), nuspojave i rizici terapije te naposlijetku i bolesnikove želje ${ }^{2}$.

Glaukom je kronična, inicijalno asimptomatska degenerativna bolest, koja zahvaća $2 \%$ populacije starije od 40 godina 7 . Pojam glaukom podrazumijeva nekoliko bolesti različite etiologije kojima je zajedničko progresivno, ireverzibilno propadanje vidnog živca i živčanih vlakana mrežnice praćeno odgovarajućim ispadima u vidnom polju. Najvažniji je rizični čimbenik za razvoj glaukoma povišeni IOT. Glaukom je drugi vodeći uzrok sljepoće u svijetu ${ }^{8}$. Jedini prevenirajući rizični čimbenik za razvoj i napredovanje glauko- ma jest IOT $^{9}$. Javlja se u svim dobnim skupinama, uključujući i djecu, s najvećom učestalošću u starijoj životnoj dobi. S obzirom na način blokade otjecanja očne vodice, postoje dva osnovna oblika glaukoma: primarni glaukom otvorenog kuta i primarni glaukom zatvorenog kuta. U glaukomu zatvorenog kuta šarenica mehanički sprječava otjecanje očne vodice, dok u glaukomu otvorenog kuta postoji povećan otpor otjecanju očne vodice na mikroskopskoj razini trabekularne mreže. Kod glaukoma otvorenog kuta, koji je i najčešći, simptomi se rijetko javljaju u ranoj fazi bolesti, stoga je nužan probir u populaciji iznad 40 godina i u krvnih srodnika već oboljelih osoba neovisno o dobi jer postoji značajna nasljedna komponenta. Cilj je liječenja glaukoma očuvanje vida i s vidom povezane kvalitete života zaustavljanjem daljnjeg oštećenja vidnog polja ili usporenjem progresije bolesti. Osnova liječenja je topička primjena lijekova (u kapima) koji snižavaju očni tlak 1-4,6-12.

Ciljevi ovog istraživanja bili su utvrditi postoji li razlika u mjerenju IOT-a GAT-om i nekontaktnim APT-om te usporediti osjećaj ugode prilikom mjerenja IOT-a objema metodama u ispitanika obaju spolova i starosti iznad 18 godina.

\section{ISPITANICI I METODE}

\section{Ispitanici}

$\mathrm{U}$ istraživanju koje je bilo ustrojeno po načelu presječnog (engl. cross-sectional) istraživanja te provedeno od listopada 2017. do travnja 2018. godine na Poliklinici za oftalmologiju "Oculus”, sudjelovala su 133 zdrava i punoljetna ispitanika obaju spolova (83 žene i 50 muškaraca) kojima je učinjen standardni oftalmološki pregled ${ }^{13,14}$. Ispitanici su na pregled došli zbog korekcije refrakcijske greške. Svi su ispitanici nakon obavijesti o načinu provođenja istraživanja potpisali informirani pristanak za dobrovoljno sudjelovanje u istraživanju. Istraživanje je odobrilo Etičko povjerenstvo Medicinskog fakulteta Osijek. Iz istraživanja su isključene osobe koje su mlađe od 18 godina, osobe koje se liječe od glaukoma, osobe koje su imale operativni zahvat na prednjem ili stražnjem segmentu oka, osobe koje imaju degenerativne promjene na prednjem segmentu oka ili teži poremećaj suznog filma. 


\section{Metode}

Istraživanje je provedeno anketnim upitnikom. Prije samog provođenja ankete, ispitanici su bili upoznati s njezinim sadržajem i svrhom provođenja te su vlastoručno potpisali informirani pristanak i suglasnost za provođenje ankete i prikupljanje podataka. U anketi su se ispitivali sljedeći podatci: spol i dob ispitanika, nošenje leća i dosadašnji broj mjerenja IOT-a. Nakon ispunjavanja općih podataka svaki ispitanik pristupio je oftalmološkom pregledu i mjerenju IOT-a GATom i APT-om. Obje metode pregleda bile su učinjene unutar desetominutnog razmaka. Osim ispunjavanja općih podataka, u anketi je bilo potrebno, nakon završetka mjerenja IOT-a, na ljestvici od 1 do 5 ocijeniti ugodnost pregleda GAT-om, odnosno APT-om.

Tablica 1. Osnovna obilježja ispitanika

\section{Broj (\%) ispitanika}

Spol

\begin{tabular}{|l|l|}
\hline Muškarci & $50(37,6)$ \\
\hline Žene & $83(62,4)$ \\
\hline
\end{tabular}

Nose li leće?

\begin{tabular}{|l|r|}
\hline Da & $19(14,3)$ \\
\hline
\end{tabular}

$\mathrm{Ne} \quad 114(85,7)$

Je li to prvi pregled intraokularnog tlaka?

\begin{tabular}{|l|c|}
\hline $\mathrm{Da}$ & $73(54,9)$ \\
\hline $\mathrm{Ne}$ & $60(45,1)$ \\
\hline Ukupno & $133(100)$ \\
\hline
\end{tabular}

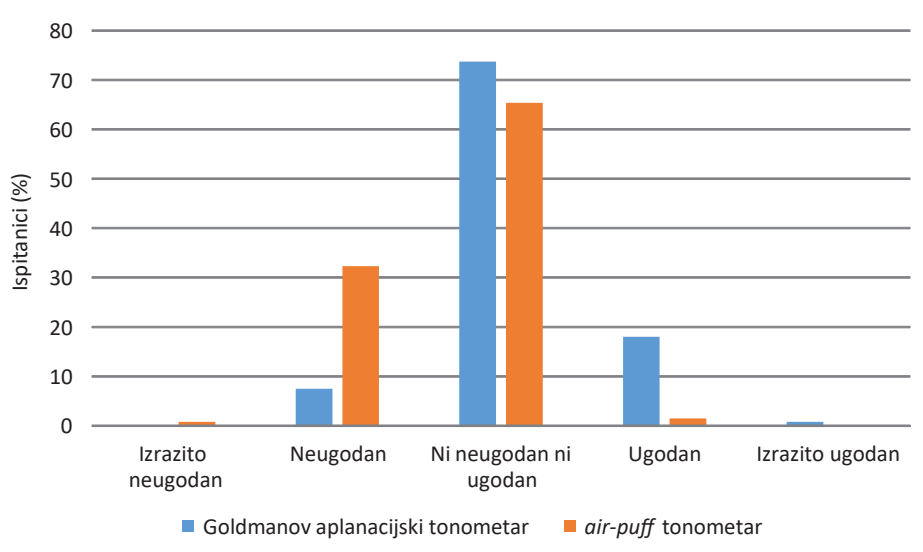

Slika 1. Raspodjela ispitanika u odnosu na ugodu mjerenja intraokularnog tlaka Goldmanovim aplanacijskim tonometrom $i$ air-puff tonometrom

\section{Statistika}

Kategorijski podatci predstavljeni su apsolutnim i relativnim frekvencijama. Numerički podatci opisani su aritmetičkom sredinom i standardnom devijacijom u slučaju raspodjela koje slijede normalnu, a u ostalim slučajevima medijanom i granicama interkvartilnog raspona. Razlike kategorijskih varijabli testirane su Fisherovim egzaktnim testom. Normalnost raspodjele numeričkih varijabli testirana je Shapiro-Wilkovim testom. Razlike normalno raspodijeljenih numeričkih varijabli između IOT-a mjerenog različitim metodama testirane su t-testom za zavisne uzorke. Usporedba dviju metoda testirana je Bland-Altmanovom analizom (odgovara na pitanje je li postojeća razlika između dviju metoda statistički značajna) i Passing-Bablokovom regresijom. Sve $P$ vrijednosti bile su dvostrane. Razina značajnosti postavljena je na $\alpha=0,05$. Za statističku analizu korišten je statistički program MedCalc Statistical Software version 18.2.1 (MedCalc Software bvba, Ostend, Belgium; http://www.medcalc.org; 2018).

\section{REZULTATI}

Istraživanje je provedeno na 133 ispitanika, od kojih je 50 (37,6 \%) muškaraca i 83 (62,4 \%) žene. Medijan dobi ispitanika bio je 51 godina (interkvartilni raspon od 37 do 62 godine). Najmlađi ispitanik imao je 18, a najstariji 86 godina. Leće je nosilo 19 (14,3\%) ispitanika, a za 73 (54,9\%) ispitanika to je bio prvi pregled IOT-a (tablica 1). Ispitanici su ocjenjivali ugodu mjerenja IOT-a GAT-om i APT-om. Prilikom mjerenja GAT-om najviše ispitanika, njih 98 (73,7\%), navelo je da pregled nije ni ugodan ni neugodan, da je ugodan navela su 24 (18\%) ispitanika, da je neugodan njih 10 (7,5 \%), a jedan $(0,8 \%)$ ispitanik opisao je mjerenje kao izrazito ugodno. Kod mjerenja APT-om jedan $(0,8 \%)$ ispitanik opisao je mjerenje kao izrazito neugodno, 43 (32,3\%) kao neugodno, 87 $(65,4 \%)$ kao niti ugodno niti neugodno, dok su dva $(1,5 \%)$ ispitanika mjerenje opisala kao ugodno. Nije utvrđena statistički značajna razlika u ocjeni ugode pregleda $u$ odnosu na metode (Fisherov egzaktni test, $P=0,180$ ) (Slika 1). Što se tiče vrijednosti izmjerenog tlaka, IOT desnog oka mjeren APT-om bio je značajno veći negoli prilikom mjerenja GAT-om (srednja razlika -2,28 mmHg, 
Tablica 2. Vrijednosti intraokularnog tlaka desnog i lijevog oka primjenom Goldmanovog aplanacijskog tonometra i air-puff tonometra

\begin{tabular}{|c|c|c|c|c|c|c|}
\hline \multirow[t]{2}{*}{ Intraokularni tlak } & \multirow{2}{*}{$\begin{array}{c}\text { Broj } \\
\text { ispitanika }\end{array}$} & \multirow{2}{*}{$\begin{array}{l}\text { Aritmetička sredina } \\
\text { (standardna devijacija) }\end{array}$} & \multirow[t]{2}{*}{ Razlika } & \multicolumn{2}{|c|}{$\begin{array}{l}95 \% \text { interval } \\
\text { pouzdanosti }\end{array}$} & \multirow[t]{2}{*}{$P^{*}$} \\
\hline & & & & Od & Do & \\
\hline \multicolumn{7}{|l|}{ Desno oko } \\
\hline Goldmanov aplanacijski tonometar & 132 & $16,99(3,5)$ & \multirow{2}{*}{$-2,28$} & \multirow{2}{*}{$-2,9$} & \multirow{2}{*}{$-1,6$} & \multirow{2}{*}{$<0,001$} \\
\hline Air-puff tonometar & 132 & $19,27(4,5)$ & & & & \\
\hline \multicolumn{7}{|l|}{ Lijevo oko } \\
\hline Goldmanov aplanacijski tonometar & 133 & $16,86(3,2)$ & \multirow{2}{*}{$-1,99$} & \multirow{2}{*}{$-2,6$} & \multirow{2}{*}{$-1,4$} & \multirow{2}{*}{$<0,001$} \\
\hline Air-puff tonometar & 133 & $18,86(4,3)$ & & & & \\
\hline
\end{tabular}

$95 \%$ raspon pouzdanosti razlike od $-2,9 \mathrm{mmHg}$ do $-1,6 \mathrm{mmHg}$; t-test za zavisne uzorke, $P<0,001)$, kao i prilikom mjerenja na lijevom oku (srednja razlika $-1,99 \mathrm{mmHg}, 95 \%$ raspon pouzdanosti razlike od $-2,6 \mathrm{mmHg}$ do $-1,4 \mathrm{mmHg}$; t-test za zavisne uzorke, $P<0,001$ ) (tablica 2). Passing-Bablokova regresijska analiza (slaganje dviju metoda) daje vrijednost odsječka za desno oko $a=-6,5$ i predstavlja konstantno, a vrijednost nagiba $b=1,5$ proporcionalno odstupanje u mjerenjima. Vrijednosti granica pouzdanosti za odsječak (95\% interval pouzdanosti od -11,1 do -2,27) i za nagib (95\% interval pouzdanosti od 1,23 do 1,8 ) upućuju na zaključak da je razlika vrijednosti nagiba statistički značajna (nema značajne razlike u linearnosti, Cusumov test linearnosti $P=0,090$, stoga je Passing-Bablokova metoda primjenjiva). Spearmanov koeficijent korelacije između metoda iznosio je $\rho=0,635(P<0,001)$. Rezidualna standardna devijacija (RSD) je mjera slučajnih razlika između dviju metoda koja za naš slučaj iznosi 2,48 mmHg, u granicama od $-4,85$ $\mathrm{mmHg}$ do $4,85 \mathrm{mmHg}$ (slika 2, slika 3). Utvrđena je statistički značajna razlika između izmjerenih vrijednosti IOT-a u desnom oku između promatranih metoda (Bland-Altmanova analiza, razlika $-2,28,95 \%$ interval pouzdanosti $-2,92$ do $-1,65$, $P<0,001)$, uzimajući u obzir da je mjerenje GAT-om „zlatni standard" (slika 3). Za lijevo oko, vrijednost odsječka je $a=-6,5$ (konstantno odstupanje), a vrijednost nagiba $b=1,5$. Vrijednosti granica pouzdanosti za odsječak (95\% interval pouzdanosti od $-12,2$ do $-3,3$ ) i za nagib (95 \% interval pouzdanosti od 1,3 do 1,8) upućuju na zaključak da je razlika vrijednosti nagiba statistički značajna (značajna je razlika u linearnosti, Cusumov test li-

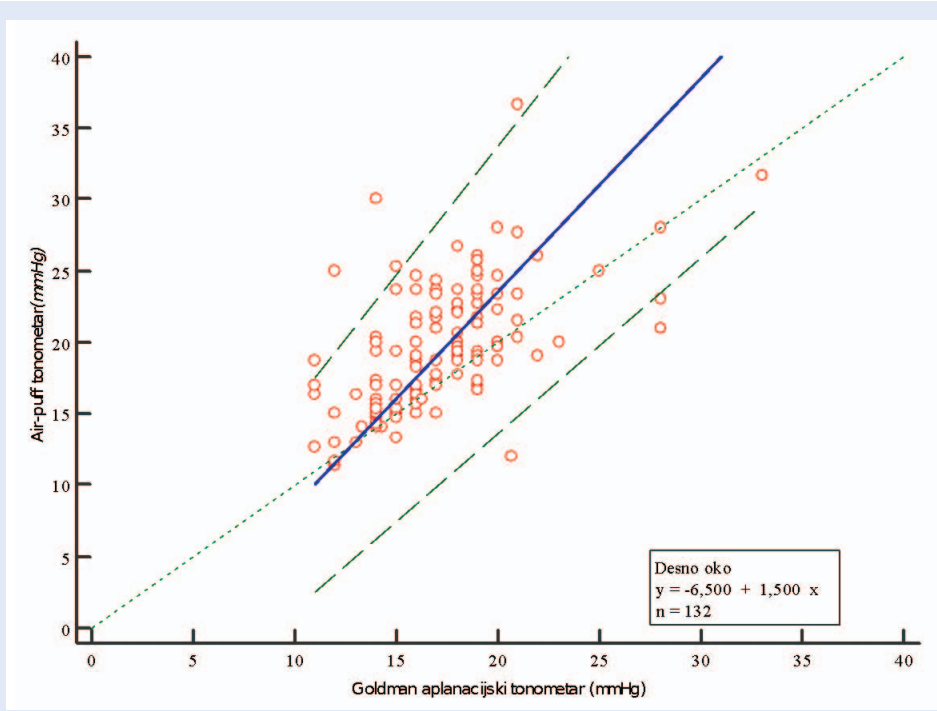

Slika 2. Intraokularni tlak izmjeren Goldmanovim aplanacijskim tonometrom i air-puff tonometrom (Passing-Bablokova regresijska analiza) na desnom oku

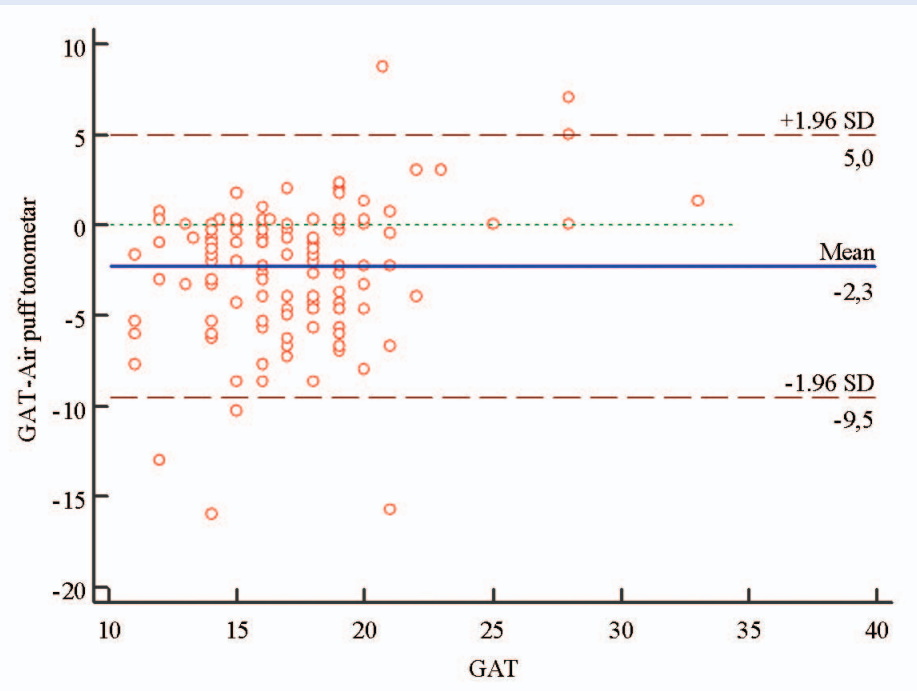

Slika 3. Bland-Altmanova analiza razlike $u$ intraokularnom tlaku desnog oka mjerenom Goldmanovim aplanacijskim tonometrom (GAT) i air-puff tonometrom (Mean - razlika, SD - standardna devijacija) 


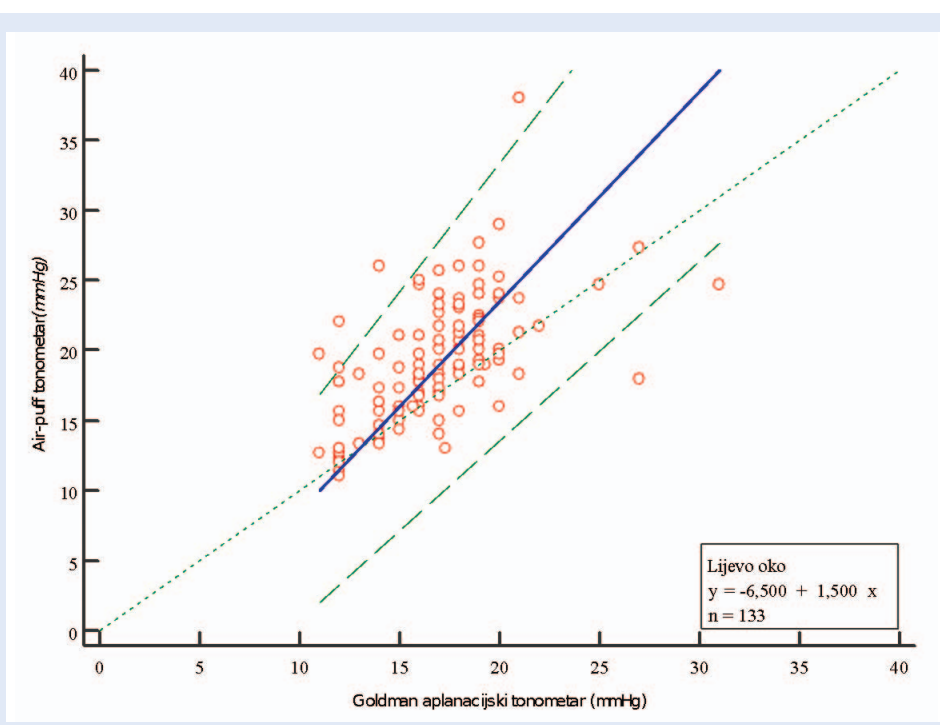

Slika 4. Intraokularni tlak izmjeren Goldmanovim aplanacijskim tonometrom i air-puff tonometrom (Passing-Bablokova regresijska analiza) na lijevom oku

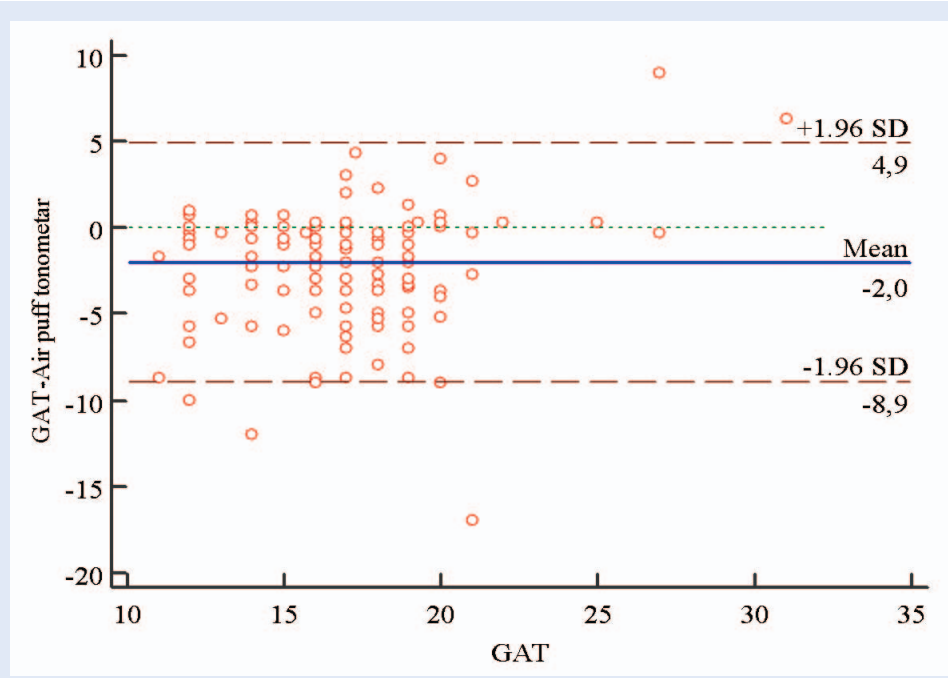

Slika 5. Bland-Altmanova analiza razlike u intraokularnom tlaku lijevog oka mjerenom Goldmanovim aplanacijskim tonometrom (GAT) i air-puff tonometrom (Mean - razlika, SD - standardna devijacija)

nearnosti $P=0,020$, stoga je Passing-Bablokova metoda neprimjenjiva). Spearmanov koeficijent korelacije između metoda iznosio je $\rho=0,634$ $(P<0,001)$. Rezidualna standardna devijacija (RSD) mjera je slučajnih razlika između dviju metoda koja za naš slučaj iznosi $2,31 \mathrm{mmHg}$, u granicama od -4,52 mmHg do 4,52 mmHg (slika 4). Utvrđena je statistički značajna razlika između izmjerenih vrijednosti IOT-a u lijevom oku između promatranih metoda (Bland-Altmanova analiza, razlika $-2,0,95 \%$ interval pouzdanosti $-2,6$ do $-1,39 P<0,001)$, uzimajući u obzir da je mjerenje GAT-om „zlatni standard” (slika 5).

\section{RASPRAVA}

Kao što je navedeno, očni tlak ili IOT pritisak je sadržaja očne jabučice na njezine stijenke ${ }^{1}$. Vrijednost IOT-a najvažniji je rizični čimbenik za razvoj i progresiju glaukoma ${ }^{7}$, zbog čega je bitno što preciznije izmjeriti IOT. Yilmaz, Altan, Aygit i suradnici proveli su presječnu studiju na ukupno 200 pacijenata kojima su mjerili IOT samo na desnom oku. U njihovoj studiji Bland-Altmanova analiza pokazala je da je srednja razlika između mjerenja IOT-a APT-om i GAT-om bila 0,6 $\pm 2,3$ $\mathrm{mmHg}$, zbog čega su zaključili da je mjerenje IOT-a APT-om usporedivo s mjerenjem IOT-a GAT-om ${ }^{8}$. Međutim, neka druga istraživanja pokazuju drugačije rezultate. Farhood u istraživanju na 98 pacijenata utvrđuje da je IOT mjeren GAT-om bio 13,06 \pm 4,774 mmHg, dok je IOT mjeren APT-om bio $15,91 \pm 6,955 \mathrm{mmHg}$. Očitovanja dobivena APT-om bila su veća nego ona dobivena GAT-om za $74 \%$ pacijenata ${ }^{5}$. Međutim, njegovi rezultati pokazali su da ne postoji značajna razlika u izmjerenom IOT-u desnog i lijevog oka među promatranim metodama, što je $u$ suprotnosti $s$ rezultatima dobivenim u ovom radu, gdje je utvrđena značajna razlika između IOT-a i desnog (Bland-Altmanova analiza, razlika -2,28, $95 \%$ interval pouzdanosti $-2,92$ do $-1,65, P<0,001)$ i lijevog oka (Bland-Altmanova analiza, razlika $-2,0$, $95 \%$ interval pouzdanosti $-2,6$ do $-1,39, P<0,001$ ) među promatranim metodama. Slično istraživanje proveli su Bang, Lee i Kim 2017. godine. Oni su uspoređivali vrijednosti IOT-a mjerene trima različitim nekontaktnim tonometrima (Canon TX - 20P, Nidek NT - 530P, Topcon CT - 1P) i GATom. Njihovo istraživanje obuhvatilo je 52 pacijenta. Rezultati tog istraživanja pokazali su da postoji statistički značajna korelacija između svakog od triju nekontaktnih tonometara i GAT-a. IOT mjeren pomoću Canon TX - 20P i Topcon CT - 1P bio je viši, a pomoću Nidek NT - 530P niži nego IOT mjeren GAT-om ${ }^{15}$. Japanski istraživači Ito, Tawara, Kubota i Harada proveli su sličnu studiju među svojim stanovništvom 2012. godine. Istraživanje je obuhvatilo 74 pacijenta kojima je IOT izmjeren dinamičnim aplanacijskim tonometrom (DCT), GAT-om i APT-om. Njihovi rezultati pokazali su da je srednji IOT izmjeren DCT-om bio $2,8 \mathrm{mmHg}$ viši 
nego IOT izmjeren GAT-om i 3,2 mmHg viši nego IOT izmjeren APT-om ${ }^{16}$. Na području Češke ovom tematikom bavili su se Ceská, Ferrová, Filous, Oskorypová, Lezatková i Sedlácková 2012. godine. Oni su u svojoj studiji koja je obuhvatila 106 ispitanika, uspoređivali vrijednosti IOT-a mjerene GAT-om, APT-om i TonoPen-om. Središnji IOT izmjeren GAT-om iznosio je 16,55 $\pm 2,95 \mathrm{mmHg}$, APT-om 17,95 \pm 4,47 te TonoPen-om 16,13 $\pm 3,4$ $\mathrm{mmHg}^{17}$. Rezultati spomenutih istraživanja, u koje se uklapaju i rezultati ovog istraživanja, potvrđuju da je GAT i dalje zlatni standard u mjerenju IOT-a. Osim što je bitno što preciznije izmjeriti IOT, gotovo je jednako važan pacijentov osjećaj ugode prilikom samog mjerenja IOT-a koji bitno utječe i na njegovu suradljivost prilikom pregleda. $U$ istraživanju koje je provedeno 1991. godine tim istraživača Brencher, Kohl, Reinke i Yolton uspoređivali su osjećaj ugode kod pacijenata prilikom mjerenja IOT-a s nekoliko različitih APT-ova (Topcon CT - 10, Reichert XPERT, Keller PULSAIR i nekontaktni tonometar Mark II) te GAT-om. Ispitanici su ocijenili Reichert XPERT kao najugodniji tonometar prilikom mjerenja IOT-a, dok je nekontaktni tonometar Mark II ocijenjen kao najneugodniji. GAT je bio u sredini po ugodnosti ${ }^{18}$. U našem istraživanju pacijenti su podjednako ocijenili ugodnost pregleda GAT-om i APT-om, odnosno nije utvrđena statistički značajna razlika u ocjeni ugode pregleda u odnosu na obje metode. lako je GAT zlatni standard u mjerenju IOT-a, u pojedinim situacijama APT ima određenu prednost jer se radi o nekontaktnom tonometru (zbog čega je minimalan rizik od prijenosa infekcija) te on ne iziskuje uporabu lokalnog anestetika (što je prednost kod pacijenata koji pokazuju alergijsku reakciju na pojedine sastojke ili cjelokupan lokalni anestetik). 1990. godine njemački istraživači Yücel, Stürmer i Gloor proveli su studiju na 126 pacijenata kojima su mjerili IOT GAT-om i APT-om te su zaključili da bi se mjerenje IOT-a APT-om moglo koristiti u pacijenata $\mathrm{s}$ povišenim rizikom od razvoja infekcija, kao i u onih s poznatim alergijskim reakcijama na sastojke lokalnih anestetika, s kornealnim edemom te poslijeoperacijski u pacijenata $s$ operacijom na prednjem očnom segmentu $^{16}$. Godine 2010. Baptista, de Sousa, Serra, Abreu i da Silva proveli su istraživanje u ko- jem su procjenjivali razinu nelagode pri izvođenju GAT-a bez upotrebe lokalnog anestetika. Svrha istraživanja bila je utvrditi hoće li razina nelagode prilikom provođenja GAT-a bez upotrebe anestezije (NAGAT) biti prihvatljiva ispitanicima. Razina boli uzrokovana GAT-om, NAGAT-om, nekontaktnim tonometrom i Schirmerov test ocijenio je trideset $\mathrm{i}$ jedan ispitanik uključen $u$ istraživanje pomoću numeričke ocjenske skale (NRS) kako bi se procijenila bol ${ }^{19}$. Ispitivači nisu našli statistički značajnu razliku između razine nelagode pri kori-

Ukoliko uspoređujemo ugodu prilikom mjerenja intraokularnog tlaka pomoću Goldmanove aplanacijske tonometrije i air-puff tonometrije, prema odgovorima ispitanika, zaključujemo da nema značajnih razlika u metodama mjerenja intraokularnog tlaka.

štenju navedenih metoda mjerenja IOT-a. Isto tako, usporedili su rezultate mjerenja IOT-a GAT-om i NAGAT-om korištenjem t-testa. Nije nađena statistički značajna razlika između vrijednosti IOT-a mjerenog GAT-om i NAGAT-om (14,0 \pm 2,0 $\mathrm{mmHg}$ i $13,8 \pm 2,0 \mathrm{mmHg}$ ). Stoga su zaključili da je moguće izvođenje NAGAT-a s prihvatljivom razinom nelagode za većinu pacijenata te bi se NAGAT trebao provoditi uz informiranje pacijenata o mogućnostima male nelagode ${ }^{19}$. U konačnici, svi navedeni rezultati upućuju na opravdanost izbora GAT-a nad APT-om. Kao i svako istraživanje, i naše istraživanje ima određena ograničenja. Jedno je od njegovih ograničenje relativno mali uzorak ispitanika (133 ispitanika) s obzirom na ukupan broj stanovnika u Osijeku. Nadalje, i dobrovoljno sudjelovanje ispitanika u istraživanju također je ograničenje studije s obzirom na mogućnost da istraživanju namjerno nisu pristupili oni ispitanici koji su prethodno imali neugodno ili bolno iskustvo prilikom mjerenja IOT-a, ali i oni ispitanici koji se boje samog mjerenja jer su čuli neugodna iskustva od drugih pacijenata. Navedena ograničenja mogla su utjecati na utvrđenu razinu ugode prilikom mjerenja IOT-a objema metodama. Unatoč navedenim ograničenjima, provedeno istraživanje pružilo je jasan uvid u istraživanu problematiku. Potrebna su daljnja, dodatna istraživanja na većem uzorku ispitanika 
kako bismo mogli dobiti točniji uvid u ovu problematiku, ali i njezino rješavanje.

\section{ZAKLJUČCI}

Na temelju provedenog istraživanja i dobivenih rezultata moguće je izvesti nekoliko zaključaka. Utvrđena je statistički značajna razlika u mjerenju IOT-a i desnog oka i lijevog oka GAT-om i APT-om u ispitanika obaju spolova i starosti iznad 18 godina. Također, većina naših ispitanika ocijenila je mjerenje IOT-a objema metodama (GAT-om i APT-om) ocjenom 3, odnosno da ispitivanje „nije ni ugodno ni neugodno". U konačnici se može zaključiti da nema značajnih razlika u ocjeni ugode mjerenja IOT-a GAT-om i APT-om. Dobiveni rezultati potvrđuju početnu hipotezu da je GAT točnija metoda mjerenja IOT-a u odnosu na APT.

Izjava o sukobu interesa: Autori izjavljuju kako ne postoji sukob interesa.

\section{LITERATURA}

1. Šikić J. Oftalmologija. 1. izdanje. Zagreb: Narodne novine, 2003;211.

2. Europsko glaukomsko društvo. Terminologija i smjernice za glaukom. 4. izdanje. Zagreb: EUGS, 2004.

3. Bušić M, Elabjer Kuzmanović B, Bosnar D. Seminaria Ophthalmologica. 3. izdanje. Osijek-Zagreb: Cerovski d.o.o., 2014;304.

4. Bradamante Ž. Oftalmologija. 1. izdanje. Zagreb: Nakladni zavod Globus, 1994;919.

5. Farhood QK. Comparative evaluation of intraocular pressure with an air-puff tonometer versus Goldmann applanation tonometer. Clin Ophthalmol 2013;7:23-27.

6. Mandić Z i suradnici. Oftalmologija. 1. izdanje. Zagreb: Medicinska naklada, 2014;272.
7. Pelčić G, Glavina I, Jakab J. Ispitivanje kvalitete života u pacijenata s glaukomom. Liječnički vjesnik 2017;139:1-2.

8. Yilmaz I, Altan C, Aygit ED, Alagoz C, Baz O, Ahmet S et al. Comparison of three methods of tonometry in normal subjects: Goldamnn applanation tonometer, non-contact airpuff tonometer, and Tono-Pen XL. Clin Ophthalmol 2014;8:1069-1074.

9. Fernandes P, Diaz-Rey JA, Queiros A, Gonzales-Meijome JM, Jorge J. Comparison of the ICARE rebound tonometer with the Goldmann tonometer in normal population. Ophthalmic Pysiol Opt 2005;25:436-40.

10. Čupak K, Gabrić N, Cerovski B i suradnici. Oftalmologija. 2. izdanje. Zagreb: Nakladni zavod za Globus, 2004.

11. Maričić Došen V. Glaukom - rana dijagnostika i liječenje. Medix 2008;14:4.

12. Knezović I. Oftalmologija za studij sestrinstva. Bjelovar: Visoka tehnička škola u Bjelovaru, 2015;163.

13. Kločić I, Vorko-Jović A. Epidemiologija. 1. izdanje. Zagreb: Medicinska naklada, 2012;290.

14. Marušić M. Uvod u znanstveni rad u medicini. 5. izd. Zagreb: Medicinska naklada, 2013;338.

15. Bang SP, Lee CE, Kim YC. Comparison of intraocular pressure as measured by three different non-contact tonometers amd Goldmann aplanation tonometer for non-glaucomatous subjects. BMC Ophthalmology 2017; 17:199.

16. Özcura F, Yildirim N, Sahin A, Çolak E. Comparison of Goldmann aplanation tonometry, rebound tonometry and dynamic contour tonometry in normal and glaucomatous eyes. Int J Ophthalmol 2015;8:299-304.

17. Ceská BM, Ferrová K, Filous A, Oskorypová K, Lezatková $\mathrm{P}$, Sedlácková P. Comparative study of intraocular pressure measurements by Goldmann aplanation tonometer, noncontact tonometer and TonoPen. Cesk Slov Oftalmol 2012;68:43-6.

18. Brencher HL, Kohl P, Reinke AR, Yolton RL. Clinical comparison of air-puff and Goldmann tonometers. J Am Optom Assoc 1991;62:395-402.

19. Baptista AM, de Sousa RA, Serra PM, Abreu CM, da Silva CM. Evaluation of discomfort of Goldmann tonometry without anaesthetic. Ophthalmic Physiol Opt 2010;30: 854-9. 